\title{
Gentamicin-impregnated collagen sponge for preventing sternal wound infection after cardiac surgery
}

\author{
Małgorzata Kozioł ${ }^{1}$, Sylwia Targońska², Janusz Stążka², Maria Kozioł-Montewka ${ }^{1}$ \\ ${ }^{1}$ Department of Medical Microbiology, Medical University of Lublin \\ ${ }^{2}$ Clinic Department of Cardiac Surgery, Medical University of Lublin
}

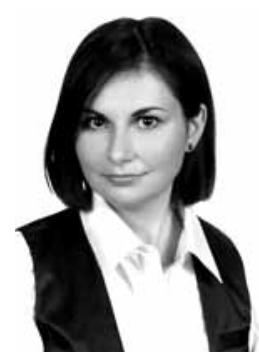

Kardiochirurgia i Torakochirurgia Polska 2014; 11 (1): 21-25

\begin{abstract}
The frequency of sternal wound infection (SWI) after cardiac surgery ranges from $0.5 \%$ to $8 \%$ and is associated with significant morbidity, mortality, and treatment cost. Perioperative antibiotic prophylaxis is not sufficient to fully prevent the contamination of the surgical access site. One of the most effective methods for the prevention of wound infection seems to be the use of gentamicin-impregnated collagen sponge, which is successfully used in abdominal and orthopedic surgery. Surgically implantable topical antibiotics can reduce wound infection in cardiac patients as well, but the efficacy of SWI prevention in cardiac surgery still raises many questions. Key words: cardiac surgery, gentamicin-collagen sponge, sternal wound infection.
\end{abstract}

\section{Streszczenie}

Częstość powikłań infekcyjnych rany posternotomijnej po zabiegach kardiochirurgicznych waha się od $0,5 \%$ do $8 \%$ i w momencie pojawienia się znacząco wpływa na pogorszenie stanu klinicznego pacjenta, wzrost śmiertelności i kosztów leczenia. Okołooperacyjna profilaktyka antybiotykowa nie pozwala w pełni zapobiec zakażeniu miejsca dostępu chirurgicznego. Jedną ze skutecznych metod prewencji infekcji ran wydaje się miejscowe podanie antybiotyku w postaci gąbki kolagenowo-gentamycynowej, która obecnie jest szeroko stosowana w chirurgii jamy brzusznej i narządów ruchu, z kolei rzadziej w kardiochirurgii. Wykorzystanie jej podczas zespolenia mostka u pacjentów kardiochirurgicznych może ograniczyć zakażenia śródpiersia i przyspieszyć gojenie rany, jednakże zastosowanie gąbki kolagenowej z gentamycyną nadal budzi wiele wątpliwości.

Słowa kluczowe: kardiochirurgia, gąbka kolagenowo-gentamycynowa, zakażenie rany mostka.

hemostasis, peri- and postoperative blood loss requiring blood product transfusion) [2]. Preventive action includes aseptic procedures, proper closure, and optimal perioperative antibiotic prophylaxis [1]. Applying antibiotic locally in the form of collagen-gentamicin sponge appears to be the perfect solution. Notwithstanding, although the sponge is used in cardiac surgery in more than 50 countries, its efficacy in preventing SWI is still being disputed [3].

\section{Microbal agents of infection and gentamicin}

Gram-positive and Gram-negative bacteria, such as Staphylococcus aureus, Staphylococcus epidermidis, Pseudomonas aeruginosa, and Escherichia coli, are the most commonly encountered microorganisms that infect bone and soft tissue [4]. In cardiac surgery, the most frequent cause of sternal wound infections is skin microorganisms - coagulase-negative staphylococci (CONS) and Staphylo- 
coccus aureus. Coagulase-negative staphylococci contribute to approximately $46 \%$ of surgical site infection cases. Being able to adhere to foreign material, such as catheters or stainless steel wires used for sternal closure, they synthesize an extracellular polysaccharide, producing a biofilm that is difficult to eliminate. In such cases, the foreign body has to be removed in order to allow proper treatment of the infection [5].

Other pathogens isolated from sternal wounds include Escherichia coli, Klebsiella, Enterobacter cloacae, and Acinetobacter. Propionibacterium acnes has also been identified as a microbal agent of SWI, which can influence sternal instability after fixation $[2,6]$.

Gentamicin is the first choice among aminoglycoside antibiotics in the treatment of serious infections. This natural antibiotic produced by Micromonospora purpurea is characterized by a wide spectrum of bactericidal action with regard to oxidative Gram-negative bacteria and some Gram-positive microorganisms. As has been demonstrated, staphylococci are sensitive to high concentrations of gentamicin [5-9].

Its bactericidal action is dependent on the concentration of the agent at the infection site [7]. The antibacterial properties result from the chemical structure of aminoglycosides. The mechanism of action is based on the blocking of protein biosynthesis, as aminoglycosides bind permanently to subunit $30 \mathrm{~S}$ of the bacterial ribosome [10]. Biological distribution is dependent on factors including age, obesity, renal function, or the presence of ascites in patients [7]. Gentamicin, like other aminoglycosides, is not well absorbed when administered orally due to its cationic nature; therefore, its administration needs to be parenteral - intravenous or intramuscular [7, 10]. In the case of intravenous administration, the agent's bioavailability is $100 \%$, and its maximum serum concentration is reached as early as 30 minutes after injection. Its biological half-life time is 2 hours for adults, and therapeutic concentration is achieved at the range of $4-10 \mathrm{mg} / \mathrm{L}$; however, intravenous administration of $>2 \mathrm{mg} / \mathrm{L}$ is considered to be toxic for the patient. The bioavailability of gentamicin administered intramuscularly is the same as in the case of intravenous administration, but a longer period of time (30-90 minutes) is required to reach maximum serum concentration. Within 24 hours, gentamicin is expelled by the kidneys in unchanged form, accumulating in the lysosomes of kidney proximal tubular cells and causing their apoptosis in clinically relevant doses. Adverse systemic effects result, therefore, from both nephrotoxic and ototoxic action [11].

Aminoglycosides have good chemical stability and do not commonly cause allergic reactions [7]. In comparison to $\beta$-lactam antibiotics, which are widely used in perioperative prophylaxis [6], aminoglycosides have a significantly narrower operating range, but they rarely induce bacterial resistance. If bacterial resistance to gentamicin does occur, it mostly consists in the breaking down of the antibiotic by various enzymes [10].

An important characteristic of aminoglycosides is their ability to act in synergy with other antibacterial agents.
The synergy effect and the ability to rapidly kill microorganisms can be observed in combination therapy, substantiating their clinical efficacy. Combining them with $\beta$-lactam antibiotics can be employed in the treatment of serious infections by Gram-negative bacteria or in the treatment of infections caused by Gram-positive bacteria, such as Staphylococcus aureus, enterococci, or Streptococcus viridans endocarditis [7].

Combining gentamicin with ultrasound is being successfully used to kill biofilm-producing bacteria, such as Escherichia coli and Pseudomonas aeruginosa, which are commonly found on implants, dialysis catheters, cardiac pacemakers, as well as on artificial vascular prostheses and heart valves [7].

\section{Local antibiotic application}

The therapeutic capabilities of systemic antibiotic administration are limited, while the local application of antibiotics is associated with numerous advantages. Most importantly, high agent concentration at the implantation site is ensured and minimum inhibitory concentration (MIC) is retained during the treatment, while adverse effects are minimized without reaching a toxic blood concentration [4].

At present, various biodegradable and nondegradable antibacterial agent carriers are being used. One of the first biomaterials available on the market was poly(methyl methacrylate) (PMMA) used in the form of bone cement or granules; the currently employed materials include hydroxyapatite (granules or porous scaffold), the natural polymer chitosan (membranes, microgranules, thermosensitive gel, sponges), and bovine tendon collagen (sponges) [7, 12-15].

Collagen sponges resorbed after the release of the drug are widely used as carriers for active substances [4]. Some of the conducted in vitro studies demonstrate that the kinetics of releasing the antibiotic from this matrix may reach as much as 95\% after as little as 1.5 hours, in comparison to $8 \%$ achieved by PMMA carriers. Local application results in the achievement of a high concentration of the therapeutic agent within several hours, which is then retained for up to 4 days [11]. Owing to these kinetic properties and to the activity of the antibiotic within a set time period, the development of microorganism resistance progresses very slowly [4]. Moreover, collagen may produce scaffolds for fibrin deposition, which results in the healing of tissue defects and acceleration of wound healing [16].

Gentamicin-collagen sponge (GMCS) is frequently used in surgery in order to prevent wound infections and to treat local infections of bone and soft tissue $[1,4]$. Local antibiotic prophylaxis is not widely used in cardiac surgery. The site of surgical access, such as sternotomy, is rarely affected by infection; however, if it does take place, it is associated with the risk of further serious complications. For this reason, additional prophylaxis is crucial, particularly in the case of high-risk patients [17].

The local application of gentamicin in the form of an absorbable collagen sponge ensures gradual release of the agent within a short time period, which improves wound 
healing without the nephrotoxic or ototoxic effect of aminoglycosides $[1,14]$. One of the studies by Friberg et al. has demonstrated that administering $260 \mathrm{mg}$ of gentamicin in between the parts of the closed sternum results in a high antibiotic concentration within 8-12 hours after the surgery [18].

The method of placing the gentamicin-collagen sponge is not without importance. It may be applied substernally, presternally, or in between the parts of the cut sternum [5]. Substernal implantation allows a high gentamicin concentration to be achieved in this region, with concurrent lower antibiotic concentration in the presternal area. This results in a significant reduction in mediastinal deep sternal wound infections (DSWI) and a slight reduction in superficial sternal wound infections (SSWI) [1]. In turn, in presternal application, the wires are partially covered, which prevents the adhesion of coagulase-negative staphylococci present in the physiological flora of the skin. It appears, therefore, that the best option is to place the matrix in between the halves of the cut sternum, which allows for a balanced release of the antibiotic in the vicinity of the sternal closure. There remains, however, a risk of reoperation due to sternal dehiscence and bleeding [5]. Literature data indicate that additional cardiac surgery interventions due to bleeding were required by approximately $4 \%$ of patients with sponges applied in this manner and by $2.3 \%$ of controls [19]. Certainly, a too thick layer of the sponge applied during sternal closure may lead to such complications; therefore, in order to reduce the high risk of postoperative bone marrow bleeding and sternal instability, a single antibiotic matrix, properly cut to match the margins of the wound, should be used (Figs. 1 and 2) [1, 5, 9].

The literature presents the advantages of the local application of antibacterial agents in surgery. Efficacious use
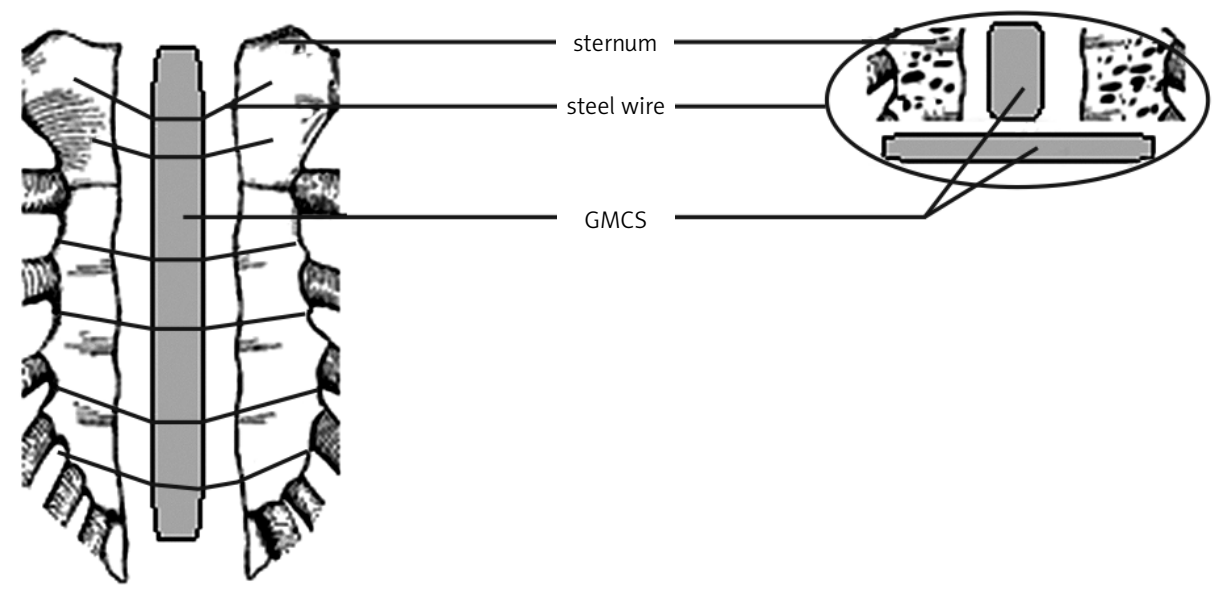

Fig. 1. Scheme - a gentamicin-collagen sponge, properly cut to size and placed in between the halves of the sternum and substernally (longitudinal and cross section) $[5,17]$
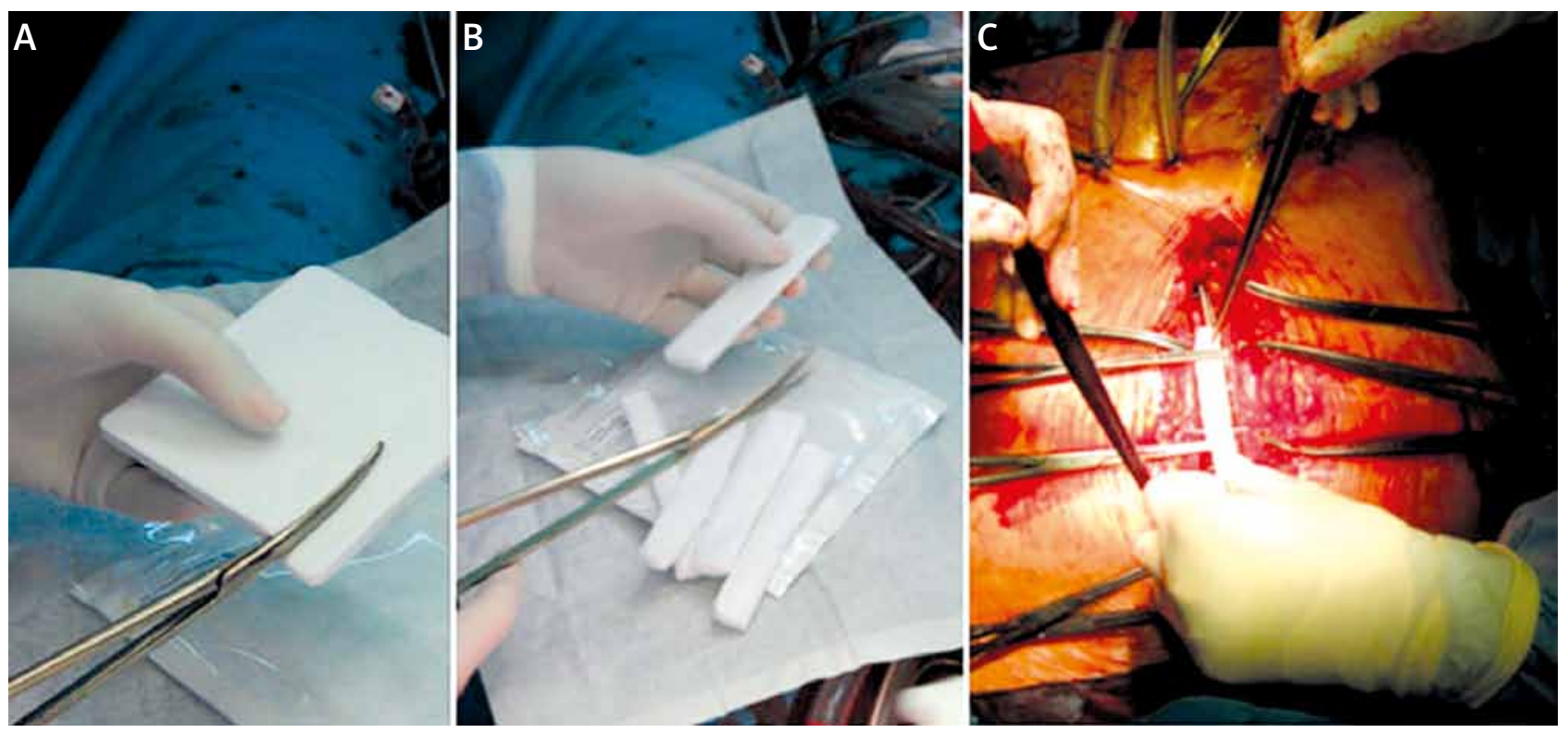

Fig. 2. A gentamicin-collagen sponge cut with sterile scissors to fit the shape of the wound, inserted under and in between the halves of the sternum after a CABG procedure 
of sponges in prophylaxis provided to cardiac surgery patients has been presented by Friberg et al., who examined 2000 patients undergoing coronary artery bypass grafting (CABG). They demonstrated a $53 \%$ reduction in postoperative SWI. In the group implanted with the sponges, postoperative complications in wound healing occurred in $4.3 \%$ of patients, as compared to $9 \%$ of patients in whom only standard perioperative antibiotic prophylaxis was used [19]. Reports from a hospital in Germany also corroborate the advantageous effect of GMCS (2.54\% vs. 6.5\%), especially with regard to DSWI reduction (0.56\% vs. 3.52\%) [1]. A medical center in the Czech Republic also reported a positive effect of this type of prophylaxis on the incidence of SWI (8.3\% vs 19.8\%) [20]. By applying a gentamicin-collagen sponge locally in between the parts of the surgically cut sternum and modifying the sternal closure procedure, low infection and mediastinitis rates can be achieved [5]. A significant reduction has been observed with regard to SWI cases caused primarily by CoNS bacterial strains, with the exception of Propionibacterium acnes bacteria refractory to aminoglycoside treatment [8]. Furthermore, redness and secretion at the surgical access site were reduced during the wound healing process in comparison with the control group [6].

Notwithstanding, similar studies conducted in other centers did not yield expected results. Birgand et al. reported $12.3 \%$ of surgical site infections within 5 years in a clinical hospital in France. Reoperation due to DSWI was required by $13.8 \%$ of patients, in comparison to $12.6 \%$ of patients implanted with GMCS. Therefore, the use of the sponges did not significantly limit the development of deep infection [21]. Similar observations were made by Raja et al.; in their study, gentamicin did not limit the occurrence of DSWI (2.1\% vs. 3.1\%), but it did influence the reduction of SSWI (2.1\% vs. $6.2 \%)$ [22].

Data collected from as many as 48 hospitals in the USA indicate the lack of a significant difference in terms of reducing infection between the study group and controls (8.4\% vs. $8.7 \%)$ with regard to both superficial and deep sternal wound infection. As underscored by the authors, multicenter studies often do not reflect results obtained in individual cases. The differences in the results may also be explained by ethnic and regional differences, as well as by the associated distribution of pathogens with varying mechanisms of resistance. For example, the American studies included a small percentage of bacterial strains that turned out to be resistant to gentamicin, including Staphylococcus epidermidis. Therefore, the differences in bacterial strains distribution condition the efficacy of agents used in prophylaxis [23].

\section{Conclusions}

Despite advanced surgical techniques, a body of science concerning the pathogenesis of surgical site infections, and the use of perioperative antibiotic prophylaxis, the incidence of these infections remains unchanged. Thus, more effective methods of prevention are required, particularly because of the rising population age and obesity, the number of type 2 diabetes patients, and the rapid emergence of resistant microorganisms [17]. While evidence indicating that local prophylaxis administered in the form of gentamicin-collagen sponge implanted at the end of cardiac surgery procedures may reduce the incidence of SWI does exist, it appears crucial for clinical practice to conduct further observation and assessment of the capabilities of GMCS due to differing opinions. Although their use is recommended for all adult patients undergoing heart surgery, it can be of greatest benefit to high-risk patients (e.g. with diabetes and/or BMI > 25).

\section{References}

1. Schimmer C, Özkur M, Sinha B, Hain J, Gorski A, Hager B, Leyh R. Gentamicin-collagen sponge reduces sternal wound complications after heart surgery: a controlled, prospectively randomized, double-blind study. J Thorac Cardiovasc Surg 2012; 143: 194-200.

2. Singh K, Anderson E, Harper JG. Overview and Management of Sternal Wound Infection. Semin Plast Surg 2011; 25: 25-33.

3. Creanor S, Barton A, Marchbank A. Effectiveness of a gentamicin impregnated collagen sponge on reducing sternal wound infections following cardiac surgery: a meta-analysis of randomised controlled trials. Ann R Coll Surg Engl 2012; 94: 227-231.

4. Kilian O, Hossain H, Flesch I, Sommer U, Nolting H, Chakraborty T, Schnettler R. Elution kinetics, antimicrobial efficacy, and degradation and microvasculature of a new gentamicin-loaded collagen fleece. J Biomed Mater Res B Appl Biomater 2009; 90: 210-222.

5. Schersten H. Modified prophylaxis for preventing deep sternal wound infection after cardiac surgery. APMIS 2007; 115: 1025-1028.

6. Friberg O, Svedjeholm R, Källman J, Söderquist B. Incidence, microbiological findings, and clinical presentation of sternal wound infections after cardiac surgery with and without local gentamicin prophylaxis. Eur J Clin Microbiol Infect Dis 2007; 26: 91-97.

7. Kumar CG, Himabindu M, Jetty A. Microbial biosynthesis and applications of gentamicin: a critical appraisal. Crit Rev Biotechnol 2008; 28: 173-212.

8. Friberg O. Local collagen-gentamicin for prevention of sternal wound infections: the LOGIP trial. APMIS 2007; 115: 1016-1021.

9. Friberg O, Dahlin LG, Källman J, Kihlström E, Söderquist B, Svedjeholm R. Collagen-gentamicin implant for prevention of sternal wound infection; long-term follow-up of effectiveness. Interact Cardiovasc Thorac Surg 2009; 9: 454-458.

10. Konopska B, Warwas M. Molekularne aspekty nefrotoksyczności antybiotyków aminoglikozydowych. Postepy Hig Med Dosw 2007; 61: 511-518.

11. Swieringa AJ, Goosen JH, Jansman FG, Tulp NJ. In vivo pharmacokinetics of a gentamicin-loaded collagen sponge in acute periprosthetic infection: serum values in 19 patients. Acta Orthop 2008; 79: 637-642.

12. Modrzejewska Z. Formy chitozanowe do zastosowań w inżynierii biomedycznej. Inż Ap Chem 2011; 50: 74-75.

13. Nandi SK, Mukherjee P, Roy S, Kundu B, De DK, Basu D. Local antibiotic delivery systems for the treatment of osteomyelitis - A review. Materials Science and Engineering 2009; 29: 2478-2485.

14. Defenbeck M, Mückley T, Hofmann GO. Prophylaxis and teratment of implant-related infections by local application of antibiotics. Injury 2006; 37 : 95-104.

15. Belcarz A, Ginalska G, Zalewska J, Rzeski W, Slósarczyk A, Kowalczuk D, Godlewski P, Niedźwiadek J. Covalent coating of hydroxyapatite by keratin stabilizes gentamicin release. J Biomed Mater Res B Appl Biomater 2009; 89: 102-113.

16. Jaworska-Gromaszek I, Kozioł-Montewka M, Niedźwiadek J, Ligięza J, Rudzki S, Mazurkiewicz T. Skuteczność gąbki kolagenowej zawierającej $200 \mathrm{mg}$ siarczanu gentamycyny w profilaktyce i leczeniu zakażeń miejsca operowanego. Sepsis 2010; 3: 93-96.

17. Eklund AM. Prevention of sternal wound infections with locally administered gentamicin. APMIS 2007; 115: 1022-1024.

18. Friberg O, Jones I, Sjöberg L, Söderquist B, Vikerfors T, Källman J. Antibiotic concentrations in serum and wound fluid after local gentamicin or intra- 
venous dicloxacillin prophylaxis in cardiac surgery. Scand J Infect Dis 2003; 35: 251-254.

19. Friberg O, Svedjeholm R, Söderquist B, Granfeldt H, Vikerfors T, Källman J. Local gentamicin reduces sternal wound infections after cardiac surgery: a randomized controlled trial. Ann Thorac Surg 2005; 79: 153-162.

20. Čanádyová J, Kurfirst V, Mokráček A. Użycie gąbek kolagenowych z gentamycyną przed zamknięciem mostka może obniżać ryzyko infekcji rany mostka: doświadczenia jednego ośrodka. Kardiochir Torakochir Pol 2012; 9: 415-419.

21. Birgand G, Radu C, Alkhoder S, Al Attar N, Raffoul R, Dilly MP, Nataf P, Lucet JC. Does a gentamicin-impregnated collagen sponge reduce sternal wound infections in high-risk cardiac surgery patients? Interact Cardiovasc Thorac Surg 2013; 16: 134-141.

22. Raja SG, Salhiyyah K, Rafiq MU, Felderhof J, Amrani M. Impact of gentamicin-collagen sponge (Collatamp) on the incidence of sternal wound infection in high-risk cardiac surgery patients: a propensity score analysis. Heart Surg Forum 2012; 15: 257-261.

23. Bennett-Guerrero E, Ferguson TB, Lin M, Garg J, Mark DB, Scavo VA, Kouchoukos N, Richardson JB, Pridgen RL, Corey GR; SWIPE-1 Trial Group. Effect of an implantable gentamicin-collagen sponge on sternal wound infections following cardiac surgery: a randomized trial. JAMA 2010; 304: 755-762. 